\title{
Effect of Covid-19 on Fintech
}

\author{
Lohitha $\mathbf{M}^{1}$, Dr V Harish ${ }^{2}$ \\ ${ }^{1}$ Student, PSG Institute of Management, Coimbatore \\ ${ }^{2}$ Assisstant Professor, PSG Institute of Management, Coimbatore
}

\begin{abstract}
The Covid-19 has caused disruption in almost every aspect of human life personally and professionally. Among the various sectors the finance sector has been the one that has been jolted by the pandemic across nations. Governments and organizations have resorted to use innovative technologies to overcome the challenges thrown at them. The adoption of technology in the finance domain is termed as "Fintech". Fintech witnessed its effects but they started adopting various innovative paths to tackle their business problems. This has also led to the shift in mindset of the people to adopt 'Digital' in all methods of transactions. The findings reveal that, the idea of going digital became the biggest pillar for the growth of Fintech during the pandemic. Moreover, some fintech sectors flourished during the pandemic. This paper gives insights on the different fintech sectors present in India. This also provides the reasons for the development of fintech industries during Covid-19.
\end{abstract}

\section{KEYWORDS: Fintech, Covid-19, Digital, Pandemic, Finance, Technology}

\section{INTRODUCTION}

The COVID-19 episode growingly has affected the worldwide economy and the monetary area, which assumes a basic part in alleviating the remarkable macroeconomic and financial shock brought about by the pandemic. Given the phenomenal idea of the current emergency, financial controllers and directors, national banks, alongside governments and assemblies face difficulties to keep up with economic steadiness, protect the well-working center business sectors, and guarantee the progression of credit to the real economy. The idea of the pandemic combined with the speed of transmission has expected social orders to embrace wilful behaviour changes viz., social distancing or government regulated lockdown.

It is assessed that the spread of COVID-19 has prompted between $21 \%$ and $26 \%$ expansion, covering nearly 900 million application downloads in the overall pace of day by day downloads of finance related versatile applications, which would have likely not happened without Covid-19 (Mishra, 2020). The utilization of such portable applicationbased administrations naturally gives an appealing choice to getting to monetary administrations especially during a pandemic_-given self-or government-forced limitations to development and social separating measures, and hazard of pollution by means of genuinely dealing with cash (Sahay et al. 2020)

A financial framework is the foundation of an economic system of a country; the appropriate working and progress of financial exercises generally relies upon how well and significantly monetary frameworks work. In such instance, the monetary exercises break and face extreme outcomes. An expanding number of studies recommend that the COVID-19 pandemic has started to assault economies by causing a sharp harm in a wide range of macroeconomic markers including increase in demand, supply creation, trade exchange, saving, investments and business, which extend destitution and setting off a potential recession (Barua, 2020, Chen et al. 2020; Coibion et al. 2020; ILO, 2020, World Bank, 2020, Baldwin \& de Mauro, 2020)

Despite of high loss of humans and economy due to its spread, Covid-19 has resulted in acceleration of Fintech world i.e., financial technology in short structure. Fintech is the use of technology to carry out financial activities more effectively within a short span of time. There are different types of financial service functions which include Crowd funding, Payments, Block chain, Insurance and Lending. Covid-19 spread has significantly affected these service functions.

\section{LITERATURE REVIEW}

"Fintech" can be comprehensively characterized as innovatively empowered monetary development that outcomes in new plans of action, applications, products/services, administrations with a related material impact on monetary business sectors and establishments and the arrangement of financial administrations (Gomber et al. 2017). Commonly, it alludes to trend-setters and disruptors in the financial area that utilize the accessibility of data correspondence innovation-especially, Internet-related advances (e.g., versatile Internet) and information preparing innovations (e.g., automation, and Machine Learning) (Stoeckli et al., 2018). The most important factor which promotes the growth of fintech is the technological 


\section{"Effect of Covid-19 on Fintech"}

development providing cloud based solutions, Big data and more advanced security solutions that ensures secured services. Increased usage of mobile and increased sales through online is also the reasons for its growth.

\section{A. Crowdfunding}

Crowdfunding draws motivation from ideas like miniature money (Morduch, 1999) and publicly supporting (Poetz \& Schreier, 2012), yet addresses its own special class of fund raising, worked with by a developing number of websites devoted to the topic. Past research on charitable crowdfunding has shown that, notwithstanding its fame, it compounds social disparities, giving monetary relief fundamentally to special beneficiaries (Barcelos, 2020; Berliner \& Kenworthy, 2017). During the main year of the COVID-19 emergency, numerous Americans went to altruistic crowdfunding for assist with hospital expenses, burial service costs, lost wages, independent company support, food help, and different requirements. Hence Covid related crowdfunding expanded dramatically after March 2020 on different platforms (Saleh et al., 2021; Cadogan, 2021).

\section{B. Digital payment:}

Nilekani et al., (2019) characterizes "Digital payment' signifies an installment exchanges made through computerized/electronic modes wherein both the originator and the recipient utilize computerized/electronic medium to send or get cash."

Bećirović (2014) saw that technological development caused that the utilization of paper cash has been declining, where computerized types of installment have gotten increasingly normal, because of fast development of electronic trade (internet business). They have reasoned that e-money, which needs to be acknowledged in the market must be secure, give namelessness, versatility and empower utilization at low expenses.

Reddy \& Rakesh (2019) states that that the greater part of the clients have begun utilizing new advances and are content with the administrations given by their banks and digitalization in banking assumed a significant part in forming the new time in financial area and move towards the credit only economy.

\section{Crpto currency \& Block chain:}

Block chain is a computerized based information stockpiling framework that contains special notes through cryptography. These records are added to an information base individually in order to make an extremely long series of information so that the block chain can be supposed to be a direct chain/information chain (Wouda, 2019)

Cryptocurrency is an innovation that uses block chain, one of which is digital cash, electronic cash, or virtual cash that is in a similar manner with money in this world and this cash has no actual structure(Johannes,2020).
By utilizing this block chain innovation can make all exchanges that happen become exceptionally straightforward and each of the current information will identify with each other, and each of the existing information includes one client inside the extent of the cryptocurrency framework (Amit, 2019)

\section{Insurance:}

Innovations of one or more conventional or nonconventional market players exploiting data innovation technology to convey arrangements specific to the Insurance industry (Stoeckli et al., 2018)

Because of the development of new advancements permitting to gather and break down immense measures of information from people and items (Gidaris, 2019), behavior based Insurance models are showing up, with the possibility to empower a more incorporated connection among Insurance and Prevention, given for example the impact that behavior based Insurance estimating has with respect to singular conduct.

Innovations and Insurtech could play an important role also in enabling and supporting Insurance companies in providing Prevention services (Stoeckli et al., 2018), but this possibility is still scarcely studied in literature.

\section{E. Lending:}

Lending means the benefits through provision or material by an individual to another individual with their further reimbursement by the individual to whom did they provide or by another individual.

Lending, according to the legislation, requires compulsory compliance with the basic regulation of lending on which practice and theory of the credit process should be carried out before (Morzovo et al., 2020; Poltarykhin,2020)

The functioning and implementation of the application process of the lending system is carried out through different mechanism of lending in specific economic and financial situation (Tvaronaviciene et al 2020)

\section{OBJECTIVE}

To study the impact of Covid on the fintech sector in India.

\section{IMPACT OF COVID 19 ON FINTECH:}

The fintech industry in India has changed drastically at a lightning speed from the year of 2018. It has become one of the world's largest fintech markets after US, UK and China. Due to Covid-19 Indian Fintech new companies saw a 53\% decrease in investments in the initial a half year of 2020. But they figured out how to raise nearly USD 1.7 billion 1 through 70 deals, compared to USD 3.6 billion2 through 102 arrangements during a similar period in the earlier year. It prompted a few impacts namely the cooperation among Fintechs and NBFCs/MFIs sped up, client outreach extended, while organizations for digitalization, credit underwriting, and loans collection appeared. Some of the major impacts in different sectors are explained below: 


\section{A. Effects on Crowd funding:}

There are huge contrasts among before, then after the fact the COVID-19 flare-up. While crowdfunding in the spaces like Business, Real Estates and so on, individuals started to focus harder on clinical, mishap, and good cause. Many crowdfunding platforms did an effective role in collecting funds for Covid relief. Among them Covid relief and medical together constituted $80-90 \%$. Here is the percentage of certain crowdfunding platforms in India.

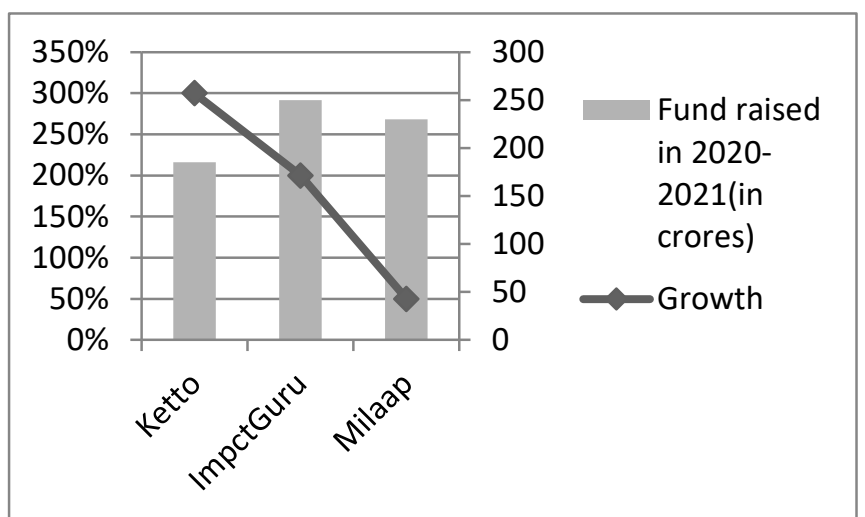

Fig 1. Source: Somvanshi, K. K. (2021, June 6)

During the first wave, the starter subject of raising money was for food for the most exceedingly terrible influenced portions, similar to day by day breadwinners and travel laborers; trailed by assets for medications and individual defensive gear for medical care and other forefront laborers.

In the second wave, crusades focused on supply of medical clinic basics, oxygen concentrators and supplies for frontline workers, just as individual missions zeroed in on remembrances and hospitalizations costs.

\section{B. Effects on Digital payments:}

Mobile based installments contacted 5895.39 exchanges in August'21, mirroring a growth rate of $1105 \%$. Due to contactless transactions and the relaxation in lockdown limitations helped the growth of digital payment.

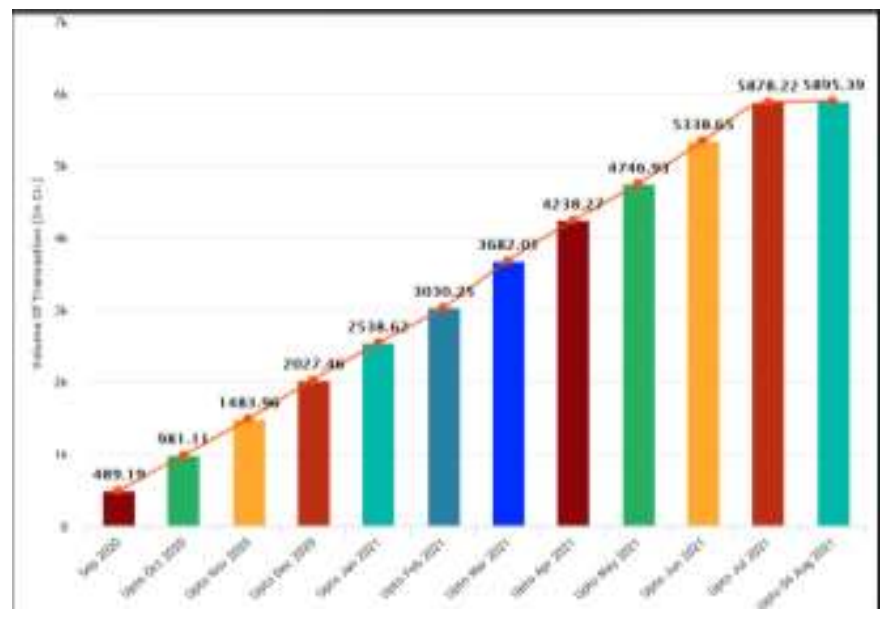

Fig 2. Source: digipay.gov.in

Added advantage is that RBI's choice to climb the cutoff for contactless card exchanges from INR 2,000 (USD 27.28) to
INR 5,000 (USD 68.2) and the passage of a few different players into the installments area, though in a reviewed way, is required to additional fuel development in this sector.

\section{Effects on Crypto currency and Block chain:}

Out of 100 million users in the World, 10\% users are in India (Kurup, R. (2021, March 21)). The lockdown has increased the crypto adoption in India sustaining the enthusiasm and its growth. During the start of covid, crypto saw a dip after the decrease in S\&P index in USA. The reason for the dip is due to a sudden increase in liquidity and lot of investors had calls that to be covered by liquidating than being invested in crypto. But, again crypto started to earn in a real quick, and the status of each crypto across the globe is shown below:

Table I. Source: Kurup, R (2021, March 21)

\begin{tabular}{|l|l|l|l|}
\hline $\begin{array}{l}\text { Crypto } \\
\text { currency }\end{array}$ & 01-Mar-20 & $\begin{array}{l}\text { 01-Mar- } \\
\mathbf{2 1}\end{array}$ & \% Change \\
\hline Bitcoin & $\$ 8,552.99$ & $\$ 46,653.00$ & $445.465 \%$ rise \\
\hline Ethereum & $\$ 218.35$ & $\$ 1,480.13$ & $577.87 \%$ rise \\
\hline $\begin{array}{l}\text { Binance } \\
\text { coin }\end{array}$ & $\$ 19.32$ & $\$ 226.76$ & $1073.55 \%$ rise \\
\hline Cardano & $\$ 0.05$ & $\$ 1.34$ & $2729.39 \%$ rise \\
\hline Tether & $\$ 1.00$ & $\$ 0.99$ & $0.4806 \%$ rise \\
\hline
\end{tabular}

Also, Block chain was used to serve different purposes other than being in business. It is used in Clinical Trial Management to reduce number of trials, medical supply chain to trace medical equipment, user privacy protection to protect user identity, data aggregation to collect data efficiently, contact tracing to track patients, donation tracking and risk estimation.

\section{Effects on Insurance:}

Moving past conventional types of paper-based arrangements, Insurance companies have empowered admittance to different kinds of protection, accessible on applications, at the press of a catch, considering higher client decision and mindfulness about protection. With the expanding interest for altered administrations and items, the business has multiplied down on "bit sized insurance" or "sachet insurance" where guarantors give security to more modest charges and decreased inclusion, which can be named per the need, time, or a particular occasion. All these factors have led to an increase in New business premium upto $55.18 \%$ as mentioned by Life Insurance council. Given, the percentage of non-insurance segments from the total premium earned: 
Non life insurance gross direct premium (Till Feb2021)

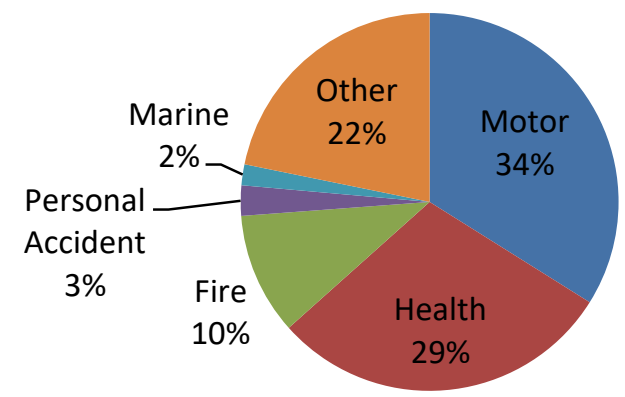

Fig 3. Source: ibef.org

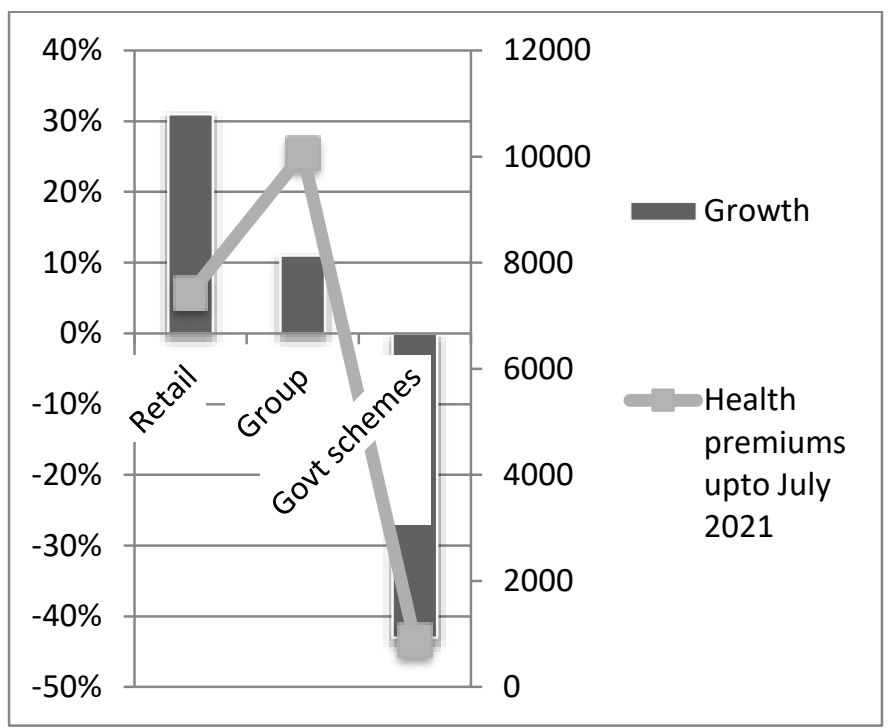

Fig 4. Source: Times of India

The above given graph shows that the health insuranceretail has increased upto $30 \%$. This rightly gives the idea of how Covid has pushed the people towards health insurance and has increased the threat of people about their lives.

\section{E. Effects on Lending:}

Indian lending FinTechs got complete subsidizing of INR 69.8 billion(USD 939 million) in FY 21, showing 16.5\% Y$\mathrm{o}-\mathrm{Y}$ development as far as venture from the past year.

Lending is maybe the most noticeably terrible influenced subclass in the FinTech area. Momentary benefit assumptions are tempered by higher credit misfortunes. Though the investment earned is comparatively higher, the number of deals has terribly decreased. This has curbed the lending opportunities for many sectors. In any case, it very well might be noticed that this sum is almost same across the years. This is due to the large round funding by Fintech which gets added to total sum of investments.

Hence the impacts of Covid on various fintech sectors entirely given as follow:
Table II. Overall Growth Of Different Sectors Of Fintech

\begin{tabular}{|c|l|l|}
\hline Sector & Growth & \multicolumn{1}{|c|}{ Reason } \\
\hline Crowd funding & $\begin{array}{l}\text { Helped the people } \\
\text { meeting their daily needs } \\
\text { and monetary needs }\end{array}$ \\
\hline $\begin{array}{l}\text { Digital } \\
\text { payments }\end{array}$ & $\begin{array}{l}\text { Helped people to use the } \\
\text { contact less method for } \\
\text { transactions }\end{array}$ \\
\hline $\begin{array}{l}\text { Block chain and } \\
\text { Cryptocurrency }\end{array}$ & & $\begin{array}{l}\text { Easy adaptability to the } \\
\text { concept of digital money }\end{array}$ \\
\hline Insurtech & $\begin{array}{l}\text { Simple transaction } \\
\text { procedures with less } \\
\text { premiums }\end{array}$ \\
\hline Lending & & $\begin{array}{l}\text { Not adapting to the } \\
\text { changing technology }\end{array}$ \\
\hline
\end{tabular}

Covid 19 has boosted the usage of gadgets, internet and contact-less transaction all over the globe. The same situation is prevailing in India also. Lending uses less of technology in its operations whereas the other technology adopted sectors like Insurtech, Block chain, Digital payments and Crowdfunding to reach greater range in less than a year. People also feel that the usage of technology eases their lives and this is the biggest flex for the fintech industry to reach millions of people.

\section{FUTURE SCOPE}

We can foresee that the changing environment, where people become more financially active, will help embedded finance flourish. In such instance, fintech can become more personalized and automated by integrating the present technology.

The mix of block chain and AI serves the base for the ultimate future which reimagines the whole idea of fintech services. Crypto becomes one of the most essential forms of exchange, vanishing the traditional money and banks. Payments will become seem less, very easy and can cross across borders. Insurtech will become a common area for all the customers and the service will become personalized, making the service reach each and every individual efficiently. In lending, the process will become significantly reduced by enabling SaaS solutions, digital contracts which decreases the administration and legal fees thereby reducing the need of greater liquidity.

In rare cases, there are greater chances for changes in the market due to economic disability but overall there will be numerous fintechs which produce commoditized technology.

\section{CONCLUSIONS}

Covid has impacted the fintech industry more with positive effects. Most of the companies contend with finance and technology to carry out their regular activities. This has elevated their normal business to a step ahead as fintech 
business. In the post covid era, high inequalities of income and wealth of a country is becoming the major concern while adopting a different technology for many countries. So, during the inclusion of a new technology, more concern should be taken so as to avoid social implications and cost.

\section{ACKNOWLEDGEMENT}

We thank our institution PSG Institute of Management for providing the best support in the preparation of this article.

\section{REFERENCES}

1. Amsyar, I., Christopher, E., Dithi, A., Khan, A. N., \& Maulana, S. (2020). The Challenge of Cryptocurrency in the Era of the Digital Revolution: A Review of Systematic Literature. Aptisi Transactions on Technopreneurship (ATT), 2(2), 153-159.

2. Baldwin, R., \& Di Mauro, B. W. (2020). Economics in the time of COVID-19: A new eBook. VOX CEPR Policy Portal, 2-3.

3. Barcelos, C. A. (2020). Go fund inequality: the politics of crowdfunding transgender medical care. Critical Public Health, 30(3), 330-339.

4. Bećirović, S. (2014). Challenges facing emoney. University Journal of Information Technology and Economics, 1, 28-36.

5. Berliner, L. S., \& Kenworthy, N. J. (2017). Producing a worthy illness: Personal crowdfunding amidst financial crisis. Social Science \& Medicine, 187, 233-242.

6. Caplinska, A., \& Tvaronavičienè, M. (2020). Creditworthiness place in Credit Theory and methods of its evaluation. Entrepreneurship and Sustainability Issues, 7(3), 2542.

7. Chandrashekar, A., Liu, J., Martinot, A. J., McMahan, K., Mercado, N. B., Peter, L., ... \& Barouch, D. H. (2020). SARS-CoV-2 infection protects against rechallenge in rhesus macaques. Science, 369(6505), 812-817.

8. Chattopadhyay, S. (2019, July 15). How the magic of medical crowdfunding works. The Hindu. https://www.thehindu.com/sci-tech/health/how-themagic-of-medical-crowdfundingworks/article28407419.ece

9. Chen, H., Qian, W., \& Wen, Q. (2021, May). The impact of the COVID-19 pandemic on consumption: Learning from high-frequency transaction data. In AEA Papers and Proceedings (Vol. 111, pp. 30711).

10. Coibion, O., Gorodnichenko, Y., \& Weber, M. (2020). The cost of the covid-19 crisis: Lockdowns, macroeconomic expectations, and consumer spending (No. w27141). National Bureau of Economic Research.
11. Dapp, T., Slomka, L., AG, D. B., \& Hoffmann, R. (2014). Fintech-The digital (r) evolution in the financial sector. Deutsche Bank Research, 11, 1-39.

12. Fu, J., \& Mishra, M. (2020). Fintech in the Time of COVID-19: Trust and Technological Adoption During Crises. Swiss Finance Institute Research Paper, (20-38).

13. Gidaris, C. (2019). Surveillance capitalism, datafication, and unwaged labour: the rise of wearable fitness devices and interactive life insurance. Surveillance \& Society, 17(1/2), 132-138.

14. Gomber, P., Koch, J.-A., \& Siering, M. (2017). Digital finance and fintech: Current research and future research directions. Journal of Business Economics, 87(5), 537-580.

15. Kurup, R. (2021, March 21). Cryptocurrencies' transaction in India soar 30 per cent during past one year.@businessline.

https://www.thehindubusinessline.com/markets/for ex/ cryptocurrencies-transaction-in-india-soar-30per-cent-during-past-one-year/article34122747.ece

16. M. Amit, R. Megnath, and S. Dipayan, "A Conceptual Study on the Emergence of Cryptocurrency Economy and Its Nexus with Terrorism Financing," in The Impact of Global Terrorism on Economic and Political Development, R. C. Das, Ed. Emerald Publishing Limited, 2019, pp. $125-138$.

17. Morduch, J. (1999). The microfinance promise. Journal of economic literature, 37(4), 1569-1614.

18. Nilekani, N., Khan, H. R., Sansi, K., Sharma, A., \& Jain, S. (2019). Report of the high level committee on deepening of digital payments. Reserve Bank of India.

19. Poetz, M. K., \& Schreier, M. (2012). The value of crowdsourcing: can users really compete with professionals in generating new product ideas? Journal of product innovation management, 29(2), 245-256.

20. Poltarykhin, A., Nosov, V., Poletaeva, L., Avdotin, V., Grishin, V., \& Babakisiyev, M. (2020). Problems of the ecological system in Russia and directions for their solution based on economic and social development programs. Journal of Environmental Management \& Tourism, 10(4 (36)), 508-514.

21. Rammy Reddy,Rakesh C. (2019). Challenges in adoption of new techonology in banking sector- a study with reference to selected private banks, Bangalore, International Journal of Management (IJM), 10(4).

https://doi.org/10.34218/IJM.10.4.2019.017 
22. Saleh, S. N., Lehmann, C. U., \& Medford, R. J. (2021). Early crowdfunding response to the COVID-19pandemic:Cross-sectional study. Journal of medical Internet research, 23(2), e25429.

23. Singh, S. (2021, February 12). Digital Lending Or Insurance Tech: Which Will Be The Most Favoured Fintech Subsector In India? Inc42 Media. https://inc42.com/datalab/the-most-favouredfintech-subsector-for-startup-investors-in-india/

24. Somvanshi, K. K. (2021, June 6). How crowdfunding is helping amid second Covid-19 wave.TheeconomicTimes.https://economictimes.in diatimes.com/news/company/ corporate-trends/etiganalysis-how-crowdfunding-is-helping-amid-

second wave/articleshow $/ 83276730 . \mathrm{cms}$ ?from $=\mathrm{mdr}$

25. Stoeckli, E., Dremel, C., \& Uebernickel, F. (2018).

Exploring characteristics and transformational capabilities of InsurTech innovations to understand insurance value creation in a digital world. Electronic markets, 28(3), 287-305.

26. Wouda, H. P., \& Opdenakker, R. (2019). Block chain technology in commercial real estate transactions. Journal of Property Investment \& Finance. 